\title{
脳傷害後の機能回復と運動学習
}

\section{Functional Recovery and Motor Learning after Brain Injury}

\section{潮見 泰藏1)}

TAIZO SHIOMI, PT, $\mathrm{PhD}^{1)}$

1) Department of Physical Therapy, School of Health Science, International University of Health and Welfare: 2600-1 Kitakanemaru, Otawara-city, Tochigi 324-8501, Japan. TEL \& Fax +81 287-24-3123

Rigakuryoho Kagaku 21(1): 87-91, 2006. Received Jan. 6, 2006.

ABSTRACT: This report describes the relationship between functional recovery and motor learning of stroke patients based on the motor learning model devised by Carr and Shepherd. In order to set stroke patients on the path to independent activities of daily living, it is important to generalize the acquired movements and to support learning under a variety of circumstances. In order to acquire higher ability, it is of key importance that we consider the task specificity of each individual case on the process of motor learning, and try to set the appropriate environmental conditions. Key words: motor learning, task, environment

要旨: 本稿では, CarrとShepherdによって考案された運動学習モデルに基づいて, 脳卒中患者の機能回復と運動学習 の関係について論じた。脳卒中患者が自立した日常生活を送るためには, 多様な条件下での学習を支援し, 獲得した 動作を汎化させることが重要である。より高い技能を獲得するには, 運動学習の過程で課題の特異性を考慮し, 適切 な環境条件を設定することが重要な鍵となる。 キーワード : 運動学習, 課題, 環境

1) 国際医療福祉大学 保健学部理学療法学科：杤木県大田原市北金丸2600-1（率324-8501）TEL 0287-24-3123 


\section{I.はじめに}

1990年代後半から2000年前半かけて, 脳科学の進歩に より脳傷害後の機能回復と大脳皮質可塑性の関係につい て多くの研究成果が得られている。理学療法の分野にも こうした新しい研究成果が徐々に取り入れられつつあ る。

APTA (米国理学療法協会)の主催によるII step conference が1990年に開催され，この会議で生態学理論やシステム 理論が提唱され, 中枢神経系機能の理論体系が著しく変 化することとなった。これを機に米国では神経生理学的 アプローチを主体とした中枢神経障害患者に対する理学 療法は大きな転換期を迎えたといえよう。特に，1932年 にBernsteinが提唱したシステム理論が注目されることに なった。この理論は, 人間の運動や行動は何らかの課題 を遂行している状態であって, その課題の達成のために いくつかのシステムが動員されたり, 組織化されたりし た結果, ある行動パターンが生じるとするものである。 これはある課題を遂行する際に, そこで行われるパ フォーマンスの制御を説明するには合理的である。中枢 神経障害による機能障害の多くは不可逆的であることか ら, 動作に関連する能力低下に対する介入が重要となる。 このため, パフォーマンスを対象とした治療理論やモデ ルが必要であり, 実際的な環境における意味のある具体 的課題を示しながら理学療法を進めていくことが求めら れる。

1990年にII step conferenceが開催されて以来，15年ぶり にIII step conferenceが昨年 7 月 15 日から21日までユタ州 ソルトレイクシティーで開催された1)。その発表テーマは 小児から成人まで非常に多岐にわたっており，発表内容 も豊富である。APTAによると，この会議における討議内 容は前回と同様, 冊子となって2007年に発刊される予定 である。

Carr とShepherdによって提案された運動学習モデル2,3) は，運動技能の獲得に心理学的諸理論を応用し，より効 果的な練習方法を考案したもので, その中にもダイナミ カル・システムズ理論による新しい知見が取り入れられ ている。

本稿では, Carr and Shepherdによって1982年に出版され た『Motor Relearning Program』のコンセプトと, さらに 2003年に出版された『機能回復トレーニングのガイドラ イン』に基づいて，脳傷害後の機能回復と運動学習の関 係について述べることにする。

\section{II. 運動制御と学習の関連}

ヒトの運動は意識的であれ無意識的であれ，周囲の環 境に合わせて実に巧みにコントロールされている。「歩 行」を例にとってみると, 歩行の開始や停止, 移動の目 標場所などは意識するが，歩行そのものはほとんど無意 識に行われる。また, 歩行する際の周囲の環境は実に多 様で, 舗装してある道もあれば砂利道や坂道, 岩だらけ の山道もあれば，滑りやすい雪道や凍結路の上を，ヒト は実にうまく歩くことができる。このようなことを可能 にするには，脳内で作られた実行指令にもとづく運動だ けでは困難で, 時々刻々と変化する環境に関する情報を, 様々な感覚受容器を通して中枢神経系に送り込み, その 感覚情報を常に勘案しながら運動の実行指令を練り直す ことで，合目的で意味のある運動を可能にしていると考 えられる。このような複雑な過程を脳は瞬時に処理して いる。さらに, 反復練習することによって運動は学習・ 記憶され，無意識でスムーズな運動が獲得されている。 ところが，疾患や障害によって運動制御システムがうま く働かない場合には，随意的な運動・動作が困難となる ため, 機能回復（運動制御能力の向上）のためのトレー ニング（リハビリテーション）が必要となる。

Carrらは脳卒中患者の運動制御に関する仮説として, 以下の点を挙げている2)。

(1) 歩く, 手を伸ばす，立ち上がるといった運動課題の 遂行能力を再獲得することには「学習」の過程が含 まれる。さらに，障害者は健常者とまったく同様に 学習しなければならない。すなわち, 障害者は練習 し，フィードバックを受け，学習の目標を理解する 必要がある。

(2)運動制御を予測的調節と同時進行的調節の両面で トレーニングする。すなわち, 姿勢調節と問題とし ている上下肢の動きは相互に関連している。

(3) る特定の課題を遂行する上でのコントロールを獲 得するには, その特定の課題で行うことが最善であ る。さらに，そのような課題はさまざまな環境を設 定し，その中で練習する必要がある。

(4) 運動課題に関係した感覚入力は，行動を調整するの に役立つ。

\section{III. 学習と回復を促すための環境設定}

ラットを用いた実験では, 脳傷害後にリッチな環境 (rich environment）におくことによって, 大脳皮質の厚さ， タンパク質濃度，シナプスの分岐化およびシナプス接合 
部のサイズの増加が起こり，パフォーマンスの向上が認 められる4-6)。

欧米の脳卒中ユニット（stroke unit）における多角的な チームアプローチによるリハビリテーション環境の有効 性については，無作為化比較対照試験の結果により証明 され，国際的にもコンセンサスが得られている。なお， 脳卒中ユニットの有効性は, 歩行能力, 日常生活活動, 自宅復帰率, 在院日数, 医療費, 生存率について認めら れている。この脳卒中ユニットは理学療法室における ADLと病棟とのADLに差が無いこと, 家族への指導・教 育が積極的に行われること，等の特徴をもつが，これは まさにヒトにおける rich environmentといえる。その根拠 は運動・練習の効果は介入量に応じてその介入した課題 に特異的に認められることが示唆されている。

この点について, Carrらはグループトレーニングエク ササイズを提案している3)。すなわち，セラピストが1日 に一人の患者に割ける時間は限られているため, トレー ニングや練習の量を増すために，1対1の個別のセラピー から，セラピストの直接の監視から少し離れたグループ セラピーへと患者自身がプログラムをこなしていくモデ ルに移行していくことである。

\section{IV. 運動再学習プログラムのねらい}

運動再学習プログラム（Motor Relearning Program）と は，1982年にCarrとShepherdによって考案され，その仮説 によると, 長く運動療法の拠り所となっていた「神経発 達学の原理」に基づいて運動行動をトレーニングするの ではなく，運動技能はある機能的順序にしたがって獲得 されるというのである。

運動技能の学習には4つの必須項目がある。プログラム はこれらの項目に基づいて作られている（表）。これらは 脳卒中後の運動コントロールを再学習する場合にも必須 のものと考えられる。この 4 つの必須項目とは，1）不必 要な筋活動を取り除くこと，2）フィードバック，3）練 習，4）姿勢調節と運動の相互関係である。なお，運動技 能とは,「練習の結果, より洗練され効果的に目標を達成 しうるようになったすべての動作」と定義される。日常 生活の諸動作は, 椅子から立ち上がるような一見単純な 動作であっても運動技能を要するのである。

そして, Carr and ShepherdはMRPでは環境とのやりと りのある具体的な課題を取り上げている。第二版のA Motor Relearning Program for Storkeによると，1）上肢機 能，2）口腔顔面機能，3）ベッドからの起き上がり，4） バランスのとれた座位バランス，5）立ち上がりと着座，

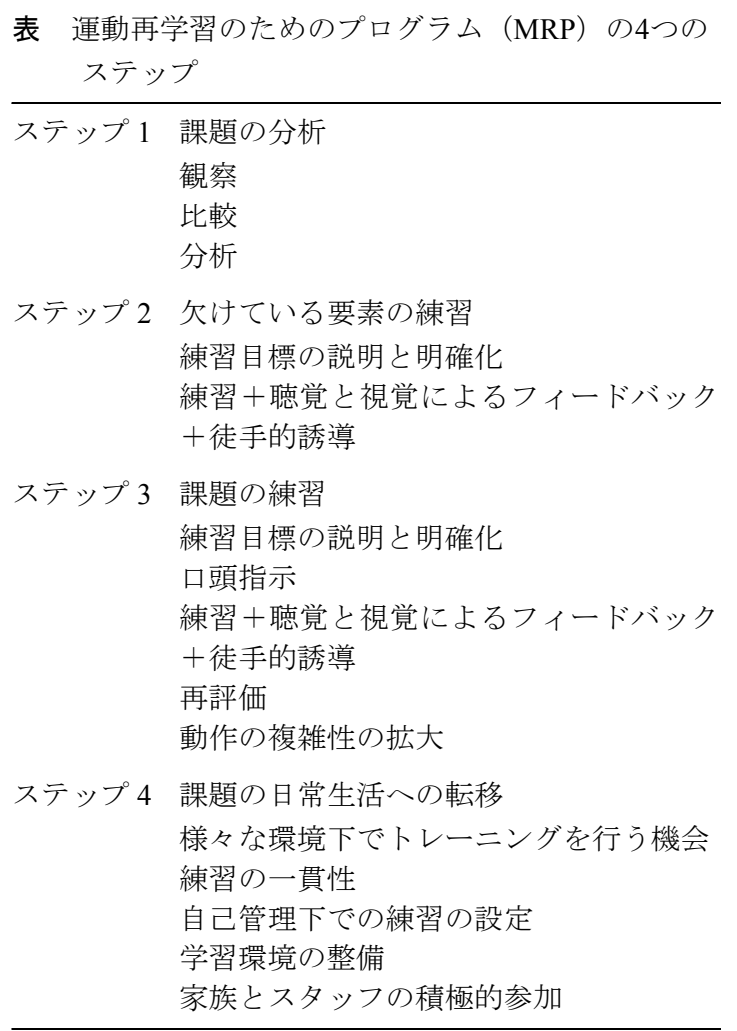

6）バランスのとれた立位，7）歩行について，それぞれ 具体的手順を解説している。

各課題に共通して，セラピストが計画して行うべき内 容は表に示すとおり 4 つのステップから成っている。こ のプログラムを進める上で考慮すべきこととして，以下 の3点が挙げられる。

(1) 運動課題を一連の全体動作として練習すること 各要素を別々に練習した後，ただちに全体を通した 動作の練習を行う。

(2) 患者に対する教示内容に関連したテクニックの利用 目標設定の方法と，どのようにその目標に到達する かということを指導することであり，その具体的方 法として, 視覚と聴覚によるフィードバックと徒手 誘導が用いられる。

(3) 運動学習の進め方

より複雑な運動を可能とするには, 徒手誘導や フィードバックを減らし, 速度を変え, 多様性を付 加することが必要となる。患者は動作の中で技能を 再獲得していくので，異なった環境条件下におくこ とが重要である。こうした過程を通じて患者のパ フォーマンスは改善し, 開かれた環境下での課題遂 行に要求される動作の幅（自由度）を広げることが 
可能となる。

このプログラムを通して強調することは，1）患者が特 定の運動課題を意識して練習すること，2）筋活動を引き 出し, 運動をコントロールできる能力を自覚させること, 3)課題を学習し技術を獲得できるように練習をより自動 的に行える水準まで高めることである。

\section{V. 運動課題の特異性ならびに環境条件の設定}

ある特定の運動課題の練習, コントロールされた筋活 動のトレーニング, そしてこれらの課題の運動要素全体 をコントロールするトレーニングを特に強調している。 運動トレーニングの㸚らいは, 主に筋のコントロールで ある。すなわち, セラピストは特定の運動課題に結びつ かないモーター・ユニットの活動まですべて引き出すの ではなく, 再学習しつつある特定の課題に応じた適当な 数のモーター・ユニットの活動をコントロールするよう 援助する。

リハビリテーションとは，患者にとって意味のある実 際の日常生活活動を再学習することであり, それは実際 の生活活動に結びつかない練習をしたり，促通したりす るものではない。患者が特定の運動課題を意識して練習 すること, それに課題を学習し技術を獲得できるように 練習をより自動的に行える水準まで高めることである。

歩行練習を例にとると, 歩行補助具を使用寸る場合, ある器具からの介助量を軽減して別の器具を用いて進め られることが多い。この場合, 介助量の多寊によって, その患者の進歩の程度を判定する基準として用いられ る。しかし, これでは, 平行棒や手すりを使って歩行練 習した患者は四脚杖を使って歩行練習する時に, まった く別の課題を新たに学習し直さなくてはならない点が軽 視されてしまっている。四脚杖による歩行練習では, 介 助なしでの歩行とまったく異なった運動学ならびに運動 力学的条件に基づく方略を用いて運動学習が行われてい るはずである。これは患者がある課題を達成できたら， その次の課題も学習可能となるはずであるという仮説に 基づいている。しかし，実際には必ずしもそのようにな るとは限らないのである。

患者に学習能力があれば, リハビリテーションの環境 によって学習過程は助長される。しかし, 重要なことは, 立ち上がり動作のような課題が正確に行えても, セラピ ストがなんらかの援助をしたならば，それは立ち上がる 方法の学習を完了したことにはならないということであ る。患者が様々な環境や動作の流れの中で, 効果的にし かも意識（注意）することなく課題が遂行できてはじめ
て学習が完了したといえる。このことをセラピストがよ く理解しておくことが重要である。患者が課題を学習で きるためには，かなり変化に富んだ練習が必要となる。 このため, 学習に適した環境を設定しなくてはならない。 運動行動が転移, あるいは汎化するか否かは, その時の 環境条件に大きく依存している7)。

脳血管障害の多くは機能障害をもたらし，筋が張力を 発生する能力や運動の制御，さらにある範囲の異なった 動作のパフォーマンスに影響を及ぼす。これまでの研究 から，ある程度満足のいくレベルのスキルは，下肢に対 する機能的かつ特異的な筋力強化トレーニングと, 通常 の環境における動作のトレーニングによってのみ再獲得 されることがわかっている。その具体的な例として, 椅 子からの起立と着座運動, 歩行や階段昇降時の立脚期の 運動，床から物を拾う運動，などは下肢が上体を持ち上 げたり降ろしたりするために, 求心性および遠心性の筋 收縮が行われるという点で共通している。これらの運動 に共通寸る練習として, 踏み台昇降を行うことは有効と 思われる。実際, 踏み台昇降の反復回数をできるだけ多 くするという単純な練習方法を採用寸ることが多い。し かし, このトレーニングの秝らいは踏み台昇降練習の効 果をベッドや椅子からの起立, 歩行, 階段昇降などの運 動に転移することである ${ }^{8)}$ 。

歩行練習を例にとって説明してみる。室内歩行では, 障害物のない, 平らな床の上を, 常にセラピストの介助 上で患者がうまく歩けたとして，そうした条件でいくら 練習を繰り返しても, 実用性の面からはほとんど役に立 たない。安全性が優先されるのは当然であるが，できる だけ早期に監視下で歩行が可能となるように促すことが 重要で, その上で次のような課題を機能に応じて試みる。

1）歩行中に急に停止する

2）歩行中に呼び止め，その方向に振り返させる

3）異なる速度（できるだけ早く, 通常の速さで，でき るだけゆっくりと）で歩く

4）障害物をよける (スラローム歩行), またぐ

5）目の前を人が横切る

6）柔らかな床材の上を歩く

7）可能であれば片手に物を持って歩く

8）人の往来の激しい場所を（人を避けながら）歩く さらに, これらの条件を複数組み合わせて行ってみる。 なお, 各課題の遂行過程でパフォーマンスに関する情 報（knowledge of performance；KP）を供与することが重 要となる。ただし，KPの与え方として，初期の段階で 「左足（麻瘏側）にしっかり体重を移して！」, 「左足（麻 痺側）をもっと大きく振り出して!」,「顔を上げて，背 
筋を伸ばして！」, というように同時に複数の指示を与え るのは情報過多となり, パフォーマンスはむしろ低下す ることになる。

\section{VI. おわりに}

脳卒中をはじめとする脳傷害患者の理学療法では, 現 実的な環境条件を前提として, 具体的な課題に対する処 理能力を高めることが重要である。すなわち, 患者は正 常な運動パターンを反復して練習寸ることよりも，一つ の日常的な機能的課題に特有の問題の解決を試みて, 課 題の遂行を学習寸ることが必要である。さらに環境の変 化一の適応が, 機能回復の重要な要素となる。なお, 誤 解のないように付言しておくが, パフォーマンスを最適 化するにはそのスキルの習熟過程で「反復すること」が 必要となることはいうまでもない。大切なことは, 理学 療法士は単に介助を与えるのではなく, 患者の学習を支 援するという点である。本稿で紹介した運動学習モデル は, その一つの具体的方法を示唆しているものといえる。

\section{引用文献}

1) Neurology Section and Section on Pediatrics of APTA: III STEP Conference. http://www.iiistep.org/IIISTEP/, APRA, 2005.

2) Carr JH, Shepherd RB: A Motor Relearning Programme for Stroke, 2nd ed. Heinemann, 1987.

3) Carr JH, Shepherd RB: Stroke Rehabilitation-Guidelines for exercise and Training to Optimaizing Motor Skill. Elsevier, Amsterdam, 2003. (潮見泰蔵, 齋藤明彦（訳）：脳卒中の運動 療法. 医学書院, 東京, 2004).

4) Kolb B, Gibb R: Environmental enrichment and cortical injury: behavioral and anatomical consequences of frontal cortex lesions. Cerebral Cortex, 1991, 1: 189-198.

5) Pritzel M, Huston JP: Unilateral ablation of telencephalon induces appearance of contralateral cortical and subcortical projection to thalamic nuclei. Behave Brain Res, 1991, 3: 43-54.

6) Will B, Kelche C: Environmental approaches to recovery of function from brain damage: animal studies. In Recovery from Brain Damage: Reflections and Directions, Plenum Press, New York, 1992, pp79-104.

7) 潮見泰藏: 脳卒中患者に対する運動スキルの最適化を図るた めの介入方略. 理学療法科学, 2004, 19(1) : 1-5.

8) 大橋ゆかり : セラピストのための運動学習 $\mathrm{ABC}$. 文光堂, 東 京, 2004. 